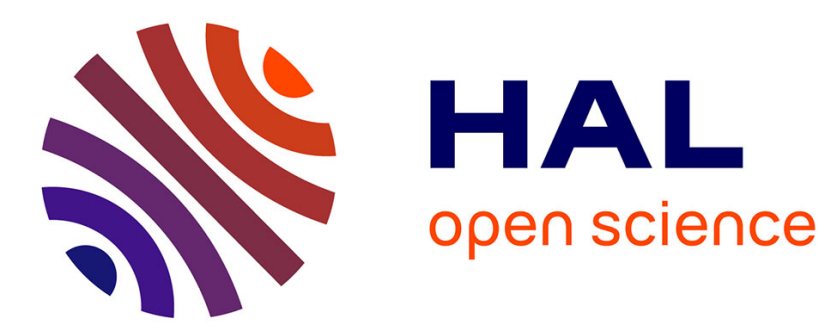

\title{
Development and use of a directory of accident databases involving chemicals \\ Jean-Philippe Pineau
}

\section{To cite this version:}

Jean-Philippe Pineau. Development and use of a directory of accident databases involving chemicals. International Conference on Safety and Reliability (ESREL 1997), Jun 1997, Lisbonne, Portugal. pp.1841-1846. ineris-00972097

\section{HAL Id: ineris-00972097 \\ https://hal-ineris.archives-ouvertes.fr/ineris-00972097}

Submitted on 3 Apr 2014

HAL is a multi-disciplinary open access archive for the deposit and dissemination of scientific research documents, whether they are published or not. The documents may come from teaching and research institutions in France or abroad, or from public or private research centers.
L'archive ouverte pluridisciplinaire HAL, est destinée au dépôt et à la diffusion de documents scientifiques de niveau recherche, publiés ou non, émanant des établissements d'enseignement et de recherche français ou étrangers, des laboratoires publics ou privés. 


\title{
DEVELOPMENT AND USE OF A DIRECTORY OF ACCIDENT DATABASES INVOLVING CHEMICALS
}

\author{
J.P.Pineau \\ Institut National de l'Environnement Industriel et des Risques (INERIS), \\ Parc technolgique Alata, B.P. 2, 60550, Verneuil en Halatte, France
}

\begin{abstract}
The aim of this review paper is a description and possible uses of a directory of accident databases involving chemicals. First, this review paper, emphasizes the requirements from end-users of accident data who need validated data for dealing with risk assessment in which they are involved. Then, a brief description of a directory of existing databases will be given. The review will end with possible ways for improving the reliability of data especially by using a framework for inclusion.
\end{abstract}

\section{KEYWORDS}

Data collection Data analysis, Reliability, Uncertainty, Accident, Hazardous material, Risk analysis.

\section{INTRODUCTION}

For long with the objective of improving the protection of environment and the avoidance of accidents, plant managers, insurers, authorities, consultants, research organisations are dealing with learning from investigations of accidents involving chemicals. Many databases on accidents implying chemicals are in existence and data are shared between dabase developers and end users. The reliability of data is strongly related to the quality of data collected from accident investigations and their subsequent analysis. Many frameworks for collecting, recording and ensuring quality are in existence but there is a need for harmonisation. Since 1993, a working group of European Safety, Reliability, and Data Association (ESReDA) "Accident Analysis (AA)" is dealing with data collection, quality, reliability and networking of accident data.

In the 1994 seminar "Accident analysis" (prepared under the auspices of the European Safety, Reliability and Data Association - ESReDA-), the need of using validated and qualified data on accidents was emphasized. In a first step, it implies the collection of reliable data. A preliminary analysis of existing databases led to the conclusion that they are generally all "abstract" databases and result from an aggregation process of existing information. During this stage, some form of "filtering" and coding of this information originating from various analysis occurs. Even in a direct collection of data by database operators, the interpretation of the initiating events, the sequence of subsequent events and the effects and causes may be difficult owing to the large variety of involved materials, plants, processes and causative factors. A methodology for direct investigation of accident was developed elsewhere and implies four main steps: gathering evidence with a search for information, exploring possible scenarios, investigating the scenarios and performing the 
validation of assumptions. More details and lessons learnt from investigations can be found in Pineau (1996).

Whatever the accident investigation could be, some explanation of the possible discrepancies between data from different databases are given by Haastrup (1994), first on an apparently well defined information such as the reported number of fatalities for the same accident. Therefore, it should be pointed out the influence of the uncertainty of data. Such findings can be extended to other types of information: chemicals and amounts involved, description of events. As a consequence, in statistical studies for quantitative risk analysis, uncertainty will be inherent in the accident case histories.

Despite these adverse conditions, the - AA - group had the objective to improve the current situation. Therefore, the involved members devoted their efforts to have a better knowledge of the requirements from end-users of accident data, to prepare a directory of existing accident databases and to define a framework for inclusion in an accident database. These three aspects will be developed in this review paper.

\section{REQUIREMENTS FROM END-USERS OF ACCIDENT DATA}

Various organisations (competent authorities, consultants, emergency planners and responders, engineering companies, general public, industrial firms, insurance and banking groups, manufacturers of equipment, research organisations and universities) can have special interests in accident data.

The most general and final objective is the improvement of the safety level of an equipment, a plant, a process or a system and the minimisation of losses.

In some countries, competent authorities can access to tailor-shaped databases for the workplace, for transport system, for a given industrial field, for large accidents implying consequences for man and environment. For the latter object, five databases could be taken into consideration: MARS at the European Union level (Rasmussen (1996)), ARIA in France (Chaugny (1994)), FACTS in Netherlands, MHIDAS (Painter (1994)) in United Kingdom and ZEMA in Germany (Brenig, (1994)). The main goal from the review of reported accidents is the definition of proactive policies regarding safety studies, emergency planning and response, the improvement of reliability of equipment and preventive and protective devices and of safety management systems.

Manufacturers, consultants and engineering companies in charge of the operation and design of equipment and plansshall be able to identify the possible hazardous situations arising from use and manufacturing of a given substance in order to define the safe operating envelope (operating conditions for which no large accident and losses are possible) of the system under consideration. Thus, the determination of failure rates is important.

Insurance and banking companies are interested in the worst case scenarios in connection with the acceptability of risk and the definition of insurance premiums and money loans.

The development of a safety culture in industry and in the large public can be improved by learning from accident (case histories) at the industry level, in the curricula of scientists and in the general education.

And last but not least, accident investigation can show the lack of knowledge on the initiating causes, sequence of events in an accident scenario and convenient preventive and protective measures.

Bearing in mind these various objectives, an enquiry was set up among these possible end-users for understanding the strengths and weaknesses of existing databases (Keller, (1994)). During this investigation, 93 questionnaires originating from twelve countries and valid for further analysis were returned. One fourth of the total was sent back respectively by governmental organisations and by consultants and one third by industrial firms. The three most commonly used databases were ARIA, FACTS and MHIDAS (40\% of th answers). In this enquiry, 83, either dedicated in house or generic, different databases were mentioned. 
This analysis allowed a better understanding of the main use of the generic databases and was the input for further work in AA group. The particular aims and the important features to be found in a given database are summarised in tables 1 and 2 in which the percentage of answers from responders are given.

TABLE 1

AlMS*

\begin{tabular}{|l|c|}
\hline Supplying data for: & Percentage \\
\hline Identification of accident scenarios & $79 \%$ \\
\hline $\begin{array}{l}\text { Identification of deficiencies in design of operation of hazardous } \\
\text { installations and hazardous systems }\end{array}$ & $58 \%$ \\
\hline Evaluation of emergency procedures. & $26 \%$ \\
\hline Formulation of policies on national/international scale & $14 \%$ \\
\hline Formulation of policies for financial and insurance companies & $5 \%$ \\
\hline Validarion of models describing accidental phenomena & $17 \%$ \\
\hline Improving of total quality of management of safety & $26 \%$ \\
\hline Establishment of reliability and failure rates & $13 \%$ \\
\hline Complying with regulations and standards & $17 \%$ \\
\hline
\end{tabular}

${ }^{*}$ Multiple answers possible.

TABLE 2

IMPORTANT FEATURES*

\begin{tabular}{|l|c|}
\hline Focus & Percentage \\
\hline The accident sequence & $74 \%$ \\
\hline Chemicals involved & $60 \%$ \\
\hline Human and management aspects & $45 \%$ \\
\hline Technological aspects & $68 \%$ \\
\hline External causes & $40 \%$ \\
\hline Physical/chemical phenomena & $54 \%$ \\
\hline Human loss & $48 \%$ \\
\hline Environmental impact & $53 \%$ \\
\hline Property and plant loss & $44 \%$ \\
\hline
\end{tabular}

*Multiple answers possible.

An analysis of additional features and areas which users would like to see incorporated or improved upon in future accident databases are summarised in tables 3 and 4. Further information on this enquiry can be found in Keller (1994).

TABLE 3

AREAS FOR IMPROVEMENT

\begin{tabular}{|l|c|}
\hline & Percentage \\
\hline Identification & $49 \%$ \\
\hline Type of activities & $39 \%$ \\
\hline Chemicals involved & $49 \%$ \\
\hline Equipment involved & $44 \%$ \\
\hline Physical phenomena involved & $40 \%$ \\
\hline
\end{tabular}


TABLE 4

ADDITIONAL FEATURES

\begin{tabular}{|l|c|c|c|c|c|}
\hline Additional Feature & $\begin{array}{c}\text { Not } \\
\text { necessary }\end{array}$ & $\begin{array}{c}\text { Just for } \\
\text { information }\end{array}$ & Useful & $\begin{array}{c}\text { Highly } \\
\text { important }\end{array}$ & \\
\hline Safety Management & $7 \%$ & $14 \%$ & $50 \%$ & $29 \%$ & Useful \\
\hline Initiating cause - Man made & $4 \%$ & $2 \%$ & $23 \%$ & $71 \%$ & Highly important \\
\hline Initiating cause - Natural & $6 \%$ & $9 \%$ & $29 \%$ & $56 \%$ & Highly important \\
\hline Environment - Geography & $6 \%$ & $23 \%$ & $40 \%$ & $31 \%$ & Useful \\
\hline Environment - Population & $4 \%$ & $27 \%$ & $40 \%$ & $29 \%$ & Useful \\
\hline Emergency response on site & $9 \%$ & $20 \%$ & $37 \%$ & $34 \%$ & Useful \\
\hline Emergency response - off site & $10 \%$ & $31 \%$ & $35 \%$ & $24 \%$ & Useful \\
\hline Consequences on man - immediate & $9 \%$ & $6 \%$ & $20 \%$ & $65 \%$ & Highly important \\
\hline Mid term consequences & $6 \%$ & $14 \%$ & $40 \%$ & $40 \%$ & Highly important \\
\hline Long term consequences & $8 \%$ & $21 \%$ & $33 \%$ & $38 \%$ & Highly important \\
\hline Financial costs & $10 \%$ & $33 \%$ & $27 \%$ & $30 \%$ & Just for information \\
\hline Gravity scale & $27 \%$ & $21 \%$ & $35 \%$ & $17 \%$ & Useful \\
\hline Violations of regulations & $10 \%$ & $23 \%$ & $43 \%$ & $24 \%$ & Useful \\
\hline References to literature & $6 \%$ & $13 \%$ & $39 \%$ & $42 \%$ & Highly important \\
\hline Quality assurances 26\% & $26 \%$ & $22 \%$ & $29 \%$ & $23 \%$ & Useful \\
\hline
\end{tabular}

\section{A DIRECTORY OF EXISTING ACCIDENT DATABASES}

The basis of the directory to be issued early in 1997 will be a description in four sections: identification, technical aspects, access conditions and use, database details. Answers to an enquiry were received from 48 database operators, but later about 40 database operators accepted the introduction of information in this directory.

The industrial areas and activities will be: chemical, explosives, mines, nuclear, oil including offshore, pesticides, refining, transport and water pollution.

The main criteria for including accidents and incidents are: chemicals involved, type of hazardous events, near miss, number of fatalities, or injuries, material and in some cases environmental losses.

When analysing in details the findings from this inquiry, it shall be pointed out that the objectives are so various that covering all the above mentioned industrial areas and activities is rather impossible even with a very extended database. It implies that specialization with experts in the field to be covered will be sought. As a consequence a better networking of database operators will be required. Another positive effect of a networking will be the avoidance of multiple entries for the same incident. Improving the networking will require the development of a common accident data collection form on the basis of these in existence at European level for the MARS database or at the OECD-UN levels. Whatever this final form could be, more efforts will be devoted first to the framework for inclusion in an accident database.

\section{FRAMEWORK FOR INCLUSION IN AN ACCIDENT DATABASE}

The main objective is the development of a framework for planning and operation accident-incident databases which will address different aspects on data collecting and recording and insure quality of data. 
Currently, the members of AA group considered that the reporting form should deal with four different aspects: facts. Emergency response, follow up and analysis. The final analysis will only be clear and consistent if a set of definitions is given for filling in the reporting form. All these conditions could be considered as the minimum set of requirements.

The facts reported should make reference to the original source of information and consider a much larger field of data than previously. Data currently available are: date, time of occurrence, location and establishment, work being done, immediate effects, accident type. The information is to be extended to people working in the area, job supervision, permits issued, procedures used, ecological components (inland, freshwater, shore, offshore), mid-term and long term effects on people and area concerned, specific process, equipment and substances involved, chain of events and suspected causes...

Regarding the emergency response (if relevant), more information is to be reported on the measures taken with chronology and organisations involved.

The follow-up is dealing with the following aspects: legal, administrative, penalties, disruption of the community life, techniques used for remediation, post-emergency survey (eco-systems, health), insurance and financial implication.

Last and not least, the final analysis should give information on causes related to the operation, environment, organisation and person, the accident category and severity, referring to accepted scales and the lessons learned. It should be pointed out that gravity scales can ease comparison and classification of accidents allowing statistics and trend analysis and improve the reliability of data. An example is the gravity scale developed at the European level for industrial accidents involving dangerous chemicals (Amendola, A. et al (1994)).

In the AA group, such a broad work is at a beginning stage, will imply database operators and will be carried out through an enquiry with some of the database operators concerned with the above mentioned directory.

For the future, more data are to be collected on equipment and safety devices failures and less technical aspects such as the influence of the human factor.

\section{CONCLUSION}

Sharing of reliable data from accidents is still questionable when looking at the variety of industrial situations, materials involved and origins of data. More efforts should be devoted to investigate accidents according to a well defined and accepted form. Improvement of the relevant use of reliable data can only occur if the collection of data is carried out using validated data collection form and a framework for inclusion of data. It is the task of ESReDA "Accident Analysis" working group to develop actions in this area. We would be very pleased to take into account any suggestion for this work and to have participation of new members.

\section{ACKNOWLEDGEMENT}

The author would like to thank all those (especially Brascamp, M., Funnemark, E., Harris, S., Keller, A.Z., Painter, D.) who participated in the ESReDA "Accident Analysis" working group since 1993 and ESReDA for funding. Poders 


\section{REFERENCES}

Amendola, A. Francocci, F. Chaugny, M. (1994) Gravity scales for classifying chemical accidents. Proceedings of the 7th ESReDA Seminar on Accident Analysis, ISPRA (Italy), October 13\&14, 1994, 5567.

Brenig, H.W., Säger, S., Uth, J. (1994) Accident Information Systems and analysis in Germany based on the federal emission protection act. Proceedings of the 7th ESReDA Seminar on Accident Analysis, ISPRA (Italy), October 13\&14, 1994, 159-169.

Chaugny, M. (1994) Experience from two years operating the ARIA database. Proceedings of the 7th ESReDA Seminar on Accident Analysis, ISPRA (Italy), October 13\&14, 1994, 127-150.

Haastrup, P. (1994). On the quality of information in accident case histories. Proceedings of the 7th ESReDA Seminar on Accident Analysis, ISPRA (Italy), October 13\&14, 1994, 295-305.

Keller, A.Z., Pineau, J.P. (1994) Initial assessment of strengths and weaknesses of current accident databases. Proceedings of the 7th ESReDA Seminar on Accident Analysis, ISPRA (Italy), October 13\&14, $1994,17-54$.

Rasmussen, K. (1996) The experience with the major accident reporting system from 1984 to 1993. Report EUR 16341 EN, Joint Research Center, European Commission; ISBN92 - 827 - 5529 - 0.

Painter, D. (1994) The use of MHIDAS and other databases within the UK Health an Safety Executive. Proceedings of the 7th ESReDA Seminar on Accident Analysis, ISPRA (Italy, October 13\&14, 1994, 151158.

Pineau, J.P. (1995) Presentation of progress of work in the "Accident Analysis" working group. Proceedings of the 9th ESReDA Seminar on "Learning from accident investigations and emergency response, Erlangen (Germany), November 15\&16, 1995.

Pineau, J:P. Lechaudel, J:F: (1996) Towards sharing of data from accidents with chemicals, 2nd European Meetin on Chemical Industry and Environment, EMChie 96, Alghero (Italy), September 11-16, 1996, 853862. 